\title{
Food safety knowledge, attitude, and practice toward compliance with abattoir laws among the abattoir workers in Malaysia
}

This article was published in the following Dove Press journal:

International Journal of General Medicine

12 April 2016

Number of times this article has been viewed

\begin{abstract}
Auwalu Abdullahi ${ }^{1-3}$
Azmi Hassan'

Norizhar Kadarman ${ }^{2}$

Ahmadu Saleh ${ }^{4}$

Yusha'u Shu'aibu Baraya ${ }^{5}$

Pei Lin Lua ${ }^{6}$

'Institute for Community

Development and Quality of

Life (i-CODE), Universiti Sultan

Zainal Abidin (UniSZA), Kampus

Gong Badak, Kuala Terengganu,

Terengganu, Malaysia; ${ }^{2}$ Faculty of

Medicine, Department of Community

Medicine, Universiti Sultan Zainal

Abidin (UniSZA), Kampus Kota, Jalan

Sultan Mahmud, Kuala Terengganu,

Terengganu, Malaysia; ${ }^{3}$ Department

of Animal Health and Husbandry,

Audu Bako College of Agriculture,

Dambatta, Kano, Nigeria; ${ }^{4}$ School

of Animal Science, Faculty of Bio-

resources and Food Industry,

Universiti Sultan Zainal Abidin

(UniSZA), Terengganu, Malaysia;

${ }^{5}$ Department of Chemical Pathology,

School of Medical Sciences, Universiti

Sains Malaysia (USM), Malaysia;

${ }^{6}$ Community Health Research

Cluster, Faculty of Health Sciences,

Universiti Sultan Zainal Abidin

(UniSZA), Kampus Gong Badak, Kuala

Terengganu, Terengganu, Malaysia
\end{abstract}

Correspondence: Auwalu Abdullahi Institute for Community Development and Quality of Life (i-CODE), Universiti Sultan Zainal Abidin (UniSZA), Kampus Gong Badak, 2 I 300 Kuala Terengganu,

Terengganu, Malaysia

Tel +2348060842220

Fax+6096687859

Email draakano930@gmail.com
Purpose: Foodborne diseases are common in the developing countries due to the predominant poor food handling and sanitation practices, particularly as a result of inadequate food safety laws, weak regulatory structures, and inadequate funding as well as a lack of appropriate education for food-handlers. The most frequently involved foods in disease outbreaks are of animal origin. However, in spite of the adequate legislation and laws governing the abattoir operation in Malaysia, compliance with food safety requirements during meat processing and waste disposal is inadequate. Therefore, the present study was designed to assess the food safety knowledge, attitude, and practice toward compliance with abattoir laws among the workers in Terengganu, Malaysia.

Materials and methods: A cross-sectional survey was conducted using simple random sampling technique in the six districts of Terengganu: two districts were used for the pilot study and the remaining four were used for the main study. One hundred sixty-five abattoir workers from the selected districts were interviewed using a structured questionnaire.

Results: The mean and standard deviation of knowledge, attitude, and practice scores of the workers were 6.02 and $1.954,45.16$ and 4.496 , and 18.03 and 3.186 , respectively. The majority of the workers $(38.8 \%$ ) had a low level of knowledge and $91.7 \%$ had a positive attitude, while $77.7 \%$ had a good practice of compliance. Sex had a significant association with the level of knowledge $(P<0.001)$ and practice $(P=0.044)$ among the workers. The females had a higher level of knowledge than the males, while the males had a better practice of compliance than females. Similarly, knowledge also had a significant $(P=0.009)$ association with the level of practice toward compliance with abattoir laws among the workers.

Conclusion: The abattoir workers had a positive attitude and good practice, but a low level of knowledge toward compliance with the abattoir laws. Therefore, public awareness, workshops, and seminars relevant to the abattoir operations should be encouraged.

Keywords: abattoir legislations, abattoir staff, KAP, compliance, Terengganu

\section{Introduction}

Foodborne diseases occur commonly in the developing countries due to the predominant poor food handling and sanitation practices, inadequate food safety laws, weak regulatory systems, lack of financial resources to invest in safer equipment, and lack of education for food-handlers. ${ }^{1}$ Foods such as meat could be regarded as a high-risk food owing to their abundant ingredients that could favor the growth of microorganisms. ${ }^{2}$ The foods most frequently involved in disease outbreaks are those of animal origin, particularly beef, poultry, pork, milk, fish, and eggs. ${ }^{3}$ There is a strong relationship between meat consumption and foodborne disease outbreaks. ${ }^{4}$ The US Centers 
for Disease Control and Prevention revealed that every year there could be outbreaks of foodborne diseases that might have resulted from foods of animal origin, causing $\sim 76$ million illnesses, 325,000 hospitalizations, and 5,000 deaths per annum. ${ }^{5}$ Still little efforts are being made, especially in the developing countries, to address these public health challenges. ${ }^{6}$ There is little information about the true level of exposure of specific populations to potential hazards, especially in the case of bacterial diseases that are transmitted by consumption of meat and meat products. ${ }^{6}$

However, in spite of the adequate legislation and laws governing the abattoir operation in Malaysia, compliance with the food safety requirements during meat processing and waste disposal are inadequate. Hence, meat-borne illnesses resulting from the consumption of contaminated meat continue to be a public health concern in the developing countries, including Malaysia. ${ }^{7-9}$ Moreover, it is very important to have a clear understanding of the interaction of the prevailing food safety, knowledge, and practices of food-handlers in reducing foodborne outbreaks. ${ }^{10}$ Furthermore, there was little or no information available on the level of food safety knowledge, attitude, and practice (KAP) regarding compliance with abattoir laws among the abattoir workers in Terengganu, Malaysia. Therefore, these could hinder the development of appropriate disease prevention and public health intervention strategies. Hence, the present study was designed to assess the food safety KAP toward compliance with abattoir laws among the workers in Terengganu.

\section{Materials and methods Study settings}

This study was conducted in four administrative districts in Terengganu, Malaysia. The selection was based on the presence of a large number of meat processing plants. Terengganu is located at latitude $5^{\circ} 19^{\prime} 48^{\prime \prime} \mathrm{N}$ and longitude $103^{\circ} 08^{\prime} 26^{\prime \prime} \mathrm{E}$ in the northeastern Peninsular Malaysia. Terengganu is bordered on the northwest by the Kelantan state, southwest by the Pahang state, and east by the South China Sea. Terengganu covers a land area of 12,995 $\mathrm{km}^{2}$ with $244 \mathrm{~km}$ of scenic coastline, overlooking the South China Sea. ${ }^{11}$ Out of the seven districts of Terengganu, Kuala Terengganu, Dungun, Kemaman, and Besut were randomly chosen for this study. There was only one government-licensed abattoir in each district except Marang that had none. In Kuala Terengganu, apart from the government-owned abattoir, there is also one licensed private poultry abattoir that was included in the study. All the participants were selected according to the inclusion and exclusion criteria for this study. However, only registered workers in licensed abattoirs in Terengganu were included in the study.

\section{Study design}

The study was a cross-sectional survey of food safety KAP toward compliance with abattoir laws among the abattoir workers in Terengganu, Malaysia.

\section{Target population}

The target population for this study was all people working in abattoirs or meat processing plants of $\sim 5 \mathrm{~km}$ radius in the four districts of Terengganu.

\section{Sample size and sampling technique}

The sample size was estimated based on the single proportion formula:

$$
\mathrm{N}=\frac{Z^{2} p q}{d^{2}}
$$

where $\mathrm{N}$ is the required sample size, $Z$ is the reliability coefficient at $95 \%$ confidence interval (1.96), $p$ is the population proportion, $q$ is equal to $1-p$, and $d$ is the acceptable error $(0.05) .^{12}$

To the best of our knowledge, there is no available literature on previous work on KAP of noncompliance with meat processing and waste disposal laws in Terengganu, Malaysia. Hence, a pilot study was conducted to compute an estimate of the value of $p$ that later was applied to calculate the sample size. Standard values that could be used in this formula to calculate sample size might be either larger or smaller of a better estimate of $p$. This procedure should be used when someone is unable to arrive at a better estimate of $p .{ }^{13}$

The following shows the overall percentages that have been calculated from our pilot studies (the value for $p$ used in this study was 89\%): knowledge, $62 \%$; attitude, $70 \%$; and practice, $89 \%$.

The pilot studies were done in two districts and were not included in the actual survey. The districts used were Setiu and Hulu Terengganu in which 100 residents and 60 abattoir workers were included to participate in the pilot study.

$$
\begin{aligned}
N & =\frac{1.96^{2} \times 0.89 \times 0.11}{(0.05)^{2}} \\
& =150+15(10 \%) \\
& =165 \text { sample size }
\end{aligned}
$$

The value for $p$ used in this study was $89 \%$, which was obtained from the overall practice score during the pilot study. 
The sample size obtained was 165 , and the pretested questionnaire was administered to each of the abattoir workers in the selected districts. Only 121 workers responded, giving a response rate of $73.3 \%$. Forty-four $(26.7 \%)$ questionnaires were not included in the study due to respondent's declinations and missing data. Simple random sampling technique was applied in the six districts of Terengganu: two districts were used for the pilot study and the remaining four districts were used for the main study.

\section{Research instrument and measurement}

A structured questionnaire was developed, which was used to conduct the pilot study; later, it was validated and used in the main study. The questionnaire was made up of four parts. In part I, questions were directed toward gaining information regarding the workers' socio-demographic characteristics, while in parts II, III, and IV, respectively, questions were asked regarding their KAP on compliance with the abattoir laws throughout the entire meat processing activities.

\section{Part I: knowledge regarding the abattoir laws}

There were ten questions in this part and the workers were asked regarding their knowledge level toward the rules and regulations governing the abattoir operations. Each question had two choices. A correct answer was given 1 score, whereas a 0 score was given for a wrong answer. The original Bloom's cut-off points, $80.0 \%-100.0 \%, 60.0 \%-79.0 \%$, and $\leq 59.0 \%$, were adapted and modified from the KAP study conducted on dengue fever prevention among the people of Male', Maldives and Bangkok in 2007. ${ }^{14}$ They were used to classify KAP into three levels. The scores for knowledge varied from 1 to 10 points and were classified into three levels as follows: 1. high level: 8-10 scores; 2 . moderate level: 6-7 scores; and 3. low level: 0-5 scores.

\section{Part II: attitude toward the abattoir laws}

This part includes questions regarding the attitude of the abattoir workers toward the abattoir laws throughout the stages in meat processing and waste disposal; it was assessed using Likert scale. There were ten positive statements. The rating scale was measured as follows: positive statement with choices strongly agree, agree, neither agree nor disagree, disagree, and strongly disagree and scores 5, 4, 3, 2, and 1, respectively.

The scores varied from 0 to 50, and all individual answers were summed up for total scores and calculated for mean. The scores were classified into three levels (positive attitude, neutral attitude, and negative attitude): 1. positive attitude:
39-50 scores; 2 . neutral attitude: $33-38$ scores; and 3 . negative attitude: $0-32$ scores.

Part III: practice regarding compliance with the abattoir laws

In this part, ten questions were included. The scores regarding compliance with the abattoir laws throughout the operation activities varied from 0 to 20 . These scores were classified into three levels. The ten items were assessed as zero-one indicator (dichotomous) variables. The variables were given the value zero for "no" and value one for "yes." They were classified as good practice, fair practice, and poor practice as follows: 1. good level: 18-20 scores; 2. fair level: 11-17 scores; and 3. poor level: 0-10 scores.

\section{Ethical consideration}

Permission to conduct the research was approved by Universiti Human Resource Ethics Committee (UHREC) and Department of Veterinary Services, Ministry of Agriculture and Agro-allied Product Kuala Lumpur as well as Terengganu State Director of Veterinary Services. The names of the participants in all the abattoirs were not stated after data collection, analysis, and presentation; so as to ensure confidentiality. Participants in the study were given all the information regarding the study and signed the informed consent form before they were recruited into the study.

\section{Data analysis and statistical application}

Data entry and analysis was performed using Statistical Package for the Social Sciences, Version 20. The questionnaires were weighed to check the accuracy of the data entry by data cleansing and exploration method in the database. Descriptive statistics such as frequency (\%) for categorical data and mean and standard deviation (SD) for numerical data was used primarily to summarize and describe the data to make them more graspable. $\chi^{2}$ test was also used to find the relationship between the sociodemographic characteristics with knowledge and practice scores. Finally, the correlation was used to check the relationship between knowledge and practice as well as attitude and practice scores among the workers.

\section{Results \\ Demographic information of the abattoirs workers}

One hundred and twenty-one participants completed the survey questionnaires. Table 1 shows that the majority of the participants were males $(63.6 \%)$. The mean age of the participants was 
Table I Demographic characteristics of the abattoir workers $(n=121)$

\begin{tabular}{|c|c|c|c|}
\hline Characteristics & Mean (SD) & Number & Percentage \\
\hline \multicolumn{4}{|l|}{ Sex } \\
\hline Male & & 77 & 63.6 \\
\hline Female & & 44 & 36.4 \\
\hline Age & $39.50(12.57)$ & & \\
\hline Minimum & $18 *$ & & \\
\hline Maximum & $69 *$ & & \\
\hline \multicolumn{4}{|l|}{ Marital status } \\
\hline Single & & 20 & 16.5 \\
\hline Married & & 98 & 81.0 \\
\hline Divorced & & 3 & 2.5 \\
\hline \multicolumn{4}{|l|}{ Ethnicity } \\
\hline Malay & & 121 & 100.0 \\
\hline \multicolumn{4}{|l|}{ Educational level } \\
\hline No education & & 4 & 3.3 \\
\hline Primary education & & 12 & 9.9 \\
\hline Secondary education & & 102 & 84.3 \\
\hline Tertiary education & & 3 & 2.5 \\
\hline \multicolumn{4}{|l|}{ Position } \\
\hline Veterinarian & & I & 0.8 \\
\hline Meat inspector & & 14 & 11.6 \\
\hline Butcher & & 18 & 14.9 \\
\hline Manager & & 2 & 1.7 \\
\hline Assistant veterinarian & & 12 & 9.9 \\
\hline Others (Unqualified) & & 74 & 61.2 \\
\hline $\begin{array}{l}\text { Duration of working } \\
\text { in an abattoir }\end{array}$ & $6.31(6.13)$ & & \\
\hline $\begin{array}{l}\text { Average number of } \\
\text { animals handled }\end{array}$ & $786.74(1,839.63)$ & & \\
\hline
\end{tabular}

Note: *Minimum and maximum ages of the respondents. Abbreviation: SD, standard deviation.

40 years with an SD of 12.57. The age ranged from 18 years to 69 years, and $81.0 \%$ were married. All the participants were Malays (100.0\%), and higher percentages were educated at the secondary school (84.3\%). The majority of the workers $(61.2 \%)$ did not state their specific position or responsibilities.

\section{Distribution of knowledge level regarding the abattoir laws}

The workers answered a total of ten close-ended questions regarding the abattoir laws. Each correct response was given 1 mark with a total of 10 marks. The mean and SD of knowledge scores of the workers were 6.02 (1.954). Table 2 shows that the majority of the workers $(38.8 \%)$ had a low level of knowledge, $33.9 \%$ had a moderate level of knowledge, and only $27.3 \%$ of the workers had a higher level of knowledge.

Among the workers, only $33.9 \%$ knew that noncompliance could result in the transmission of diseases from animal to human beings. Similarly, $50.4 \%$ of the workers knew that disposal of solid waste, blood, and effluents into the nearby river could lead to water pollution (Table 3 ).
Table 2 Distribution of knowledge level regarding compliance with the abattoir laws $(n=121)$

\begin{tabular}{lll}
\hline Level & Number $(\mathbf{n}=\mathbf{1 2} \mathbf{1})$ & Percentage \\
\hline High (8-10 scores) & 33 & 27.3 \\
Moderate (6-7 scores) & $4 \mathrm{I}$ & 33.9 \\
Low (0-5 scores) & 47 & 38.8 \\
Total & 121 & 100.0 \\
\hline
\end{tabular}

Notes: Minimum $=0 ;$ maximum $=10 ;$ mean $=6.02 ; S D=1.954$.

Abbreviation: SD, standard deviation.

\section{Attitude level toward the abattoir laws}

The attitude level of the workers regarding the abattoir laws was classified as positive, neutral, and negative (Table 4). The mean and SD of the attitude scores were 45.16 and 4.496 , respectively. The majority of the workers had a positive attitude $(91.7 \%)$ and $6.6 \%$ had a neutral attitude, while $1.7 \%$ had a negative attitude toward the abattoir laws. Table 5 shows that the majority of the workers had strongly agreed with most of the statements on attitude toward the abattoir laws.

Table 3 Number and percentage of the questions on the knowledge level regarding the abattoir laws, answered correctly by the workers $(n=|2|)$

\begin{tabular}{|c|c|c|}
\hline Questions & Number & Percentage \\
\hline $\begin{array}{l}\text { I. Noncompliance means failure to act } \\
\text { according to the rules and regulations } \\
\text { set up by the government. }\end{array}$ & 101 & 83.5 \\
\hline $\begin{array}{l}\text { 2. One of the important results of } \\
\text { compliance with abattoir laws is that it } \\
\text { helps in minimizing the spread of } \\
\text { diseases to the general public. }\end{array}$ & 112 & 92.6 \\
\hline $\begin{array}{l}\text { 3. Noncompliance does not result in } \\
\text { transmission of disease from animal } \\
\text { to human beings. }\end{array}$ & 41 & 33.9 \\
\hline $\begin{array}{l}\text { 4. The antemortem inspection should be } \\
\text { done before the animal is slaughtered. }\end{array}$ & 95 & 78.5 \\
\hline $\begin{array}{l}\text { 5. Postmortem inspection can be done } \\
\text { by any person working at the abattoir. }\end{array}$ & 59 & 48.8 \\
\hline $\begin{array}{l}\text { 6. If meat processing is done in good } \\
\text { hygienic condition, it can lead to the } \\
\text { spread of pathogens to the general public. }\end{array}$ & 106 & 87.6 \\
\hline $\begin{array}{l}\text { 7. Good personal hygiene by abattoir } \\
\text { workers can result in contamination } \\
\text { of the processed carcass. }\end{array}$ & 100 & 82.6 \\
\hline $\begin{array}{l}\text { 8. All equipments used during meat } \\
\text { processing should be properly washed } \\
\text { and sterilized after each usage. }\end{array}$ & 88 & 72.7 \\
\hline $\begin{array}{l}\text { 9. Disposal of solid waste, blood, and } \\
\text { effluents into the nearby river does } \\
\text { not cause water pollution. }\end{array}$ & 61 & 50.4 \\
\hline $\begin{array}{l}\text { 10. Provision of good sanitation to the } \\
\text { abattoir environment will help reduce } \\
\text { the spread of diseases to the } \\
\text { neighboring community. }\end{array}$ & 95 & 78.5 \\
\hline
\end{tabular}


Table 4 Distribution of attitude level toward compliance with the abattoir laws $(n=121)$

\begin{tabular}{lll}
\hline Level & Number $(\mathbf{n}=\mathbf{|}$ 2 I $)$ & Percentage \\
\hline Positive (39-50 scores) & $1 \mathrm{II}$ & 91.7 \\
Neutral (33-38 scores) & 8 & 6.6 \\
Negative (0-32 scores) & 2 & 1.7 \\
Total & 121 & 100.0 \\
\hline
\end{tabular}

Notes: Minimum =29; maximum $=50$; mean $=45.16 ; S D=4.496$.

Abbreviation: SD, standard deviation.

\section{Practice level toward compliance with the abattoir laws}

The mean and SD of the abattoir workers toward compliance with the abattoir laws were 18.03 and 3.186, respectively. Among the workers, $77.7 \%$ had a good practice, $18.2 \%$ had a fair practice, and $4.1 \%$ had a poor practice (Table 6). Most of the workers received animals that appeared healthy from farm or market (87.6\%). Table 7 indicates that $89.3 \%$ of the workers used protective clothing on a daily basis before starting operation in the abattoir, while $86 \%$ maintained the abattoir environment clean and hygienic regularly. Similarly, Table 7 also shows that most of the workers had high response toward practice concerning compliance with the abattoir laws.

\section{Comparison of knowledge and practice between the grouping variable}

There was no statistical difference found between sociodemographic variables and the level of knowledge and practice except sex. Sex had a significant association with the level of knowledge $(P<0.001)$ and practiced $(P=0.044)$
Table 6 Distribution of practice level toward compliance with the abattoir laws $(n=121)$

\begin{tabular}{lll}
\hline Level & Number $(\mathbf{n}=\mathbf{|}$ | I $)$ & Percentage \\
\hline Good (18-20 scores) & 94 & 77.7 \\
Fair (II-17 scores) & 22 & 18.2 \\
Poor (0-10 scores) & 5 & 4.1 \\
Total & 121 & 100.0 \\
\hline
\end{tabular}

Notes: Minimum $=0$; maximum $=20$; mean $=18.03 ; S D=3.816$.

Abbreviation: SD, standard deviation.

behavior regarding compliance with abattoir laws among the workers. Based on statistical analysis, Table 8 shows that females (27 [81.8\%]) had a higher level of knowledge than the males ( $\operatorname{six}[18.2 \%])$. However, based on the personal interview and observation made during the data collection, the males appeared to be more knowledgeable than the females. Similarly, Table 9 indicates that the males had the best practice behavior of compliance with abattoir laws than the females. Table 10 shows that there was statistically significant $(P=0.009)$ association between knowledge and the level of practice toward compliance with abattoir laws among the workers.

\section{Observation results}

Approximately $65.0 \%$ of the abattoirs from four different districts in Terengganu had a good location and infrastructural facilities. The proper location observed could be because the abattoirs (four) selected and surveyed were owned by the federal government of Malaysia. During the survey, $50.0 \%$ of the abattoirs had a good practice toward sanitation and

Table 5 Number and percentage of the workers' attitude toward the abattoir laws $(n=|2|)$

\begin{tabular}{|c|c|c|c|c|c|}
\hline \multirow[t]{2}{*}{ Questions } & \multicolumn{5}{|l|}{$\mathbf{N}(\%)$} \\
\hline & $\begin{array}{l}\text { Strongly } \\
\text { agree }\end{array}$ & Agree & Not sure & Disagree & $\begin{array}{l}\text { Strongly } \\
\text { disagree }\end{array}$ \\
\hline $\begin{array}{l}\text { I. All abattoirs must be registered and operated according to the laws } \\
\text { set up by the Ministry of Agriculture and Agro-based Industry. }\end{array}$ & $98(81.0)$ & $19(15.7)$ & $3(2.5)$ & $0(0.0)$ & I (0.8) \\
\hline 2. Only properly trained personnel will be allowed to work in an abattoir. & $77(63.6)$ & $38(31.4)$ & $4(3.3)$ & $2(1.7)$ & $0(0.0)$ \\
\hline $\begin{array}{l}\text { 3. All personnel working in the abattoir must be in their protective } \\
\text { clothing during operation. }\end{array}$ & $73(60.3)$ & $39(32.2)$ & $3(2.5)$ & $5(4.1)$ & $0(0.8)$ \\
\hline $\begin{array}{l}\text { 4. Any animal found with the zoonotic disease at antemortem inspection } \\
\text { must be condemned completely. }\end{array}$ & $59(48.8)$ & $20(16.5)$ & $23(19.0)$ & $19(15.7)$ & $0(0.0)$ \\
\hline $\begin{array}{l}\text { 5. The government should compensate owners whose animals are } \\
\text { found not be fit for human consumptions. }\end{array}$ & $44(36.4)$ & $29(24.0)$ & 35 (28.9) & $13(10.7)$ & $0(0.0)$ \\
\hline $\begin{array}{l}\text { 6. All meat inspection activity must be carried out only by a qualified } \\
\text { veterinarian or meat inspectors. }\end{array}$ & $85(70.2)$ & $25(20.7)$ & $9(7.4)$ & $2(1.7)$ & $0(0.0)$ \\
\hline $\begin{array}{l}\text { 7. Compliance with the abattoir laws during meat processing and waste } \\
\text { disposal can only be achieved if all proper measures are taken and followed. }\end{array}$ & $92(76.0)$ & $23(19.0)$ & $6(5.0)$ & $0(0.0)$ & $0(0.0)$ \\
\hline 8. Only clean and safe water should be used to wash all carcasses in the abattoir. & $98(81.0)$ & $20(16.6)$ & $3(2.5)$ & $0(0.0)$ & $0(0.0)$ \\
\hline $\begin{array}{l}\text { 9. Compliance with the standard methods of waste disposal is the only } \\
\text { solution that can prevent water and air pollution. }\end{array}$ & $97(80.2)$ & $21(17.4)$ & $3(2.5)$ & $0(0.0)$ & $0(0.0)$ \\
\hline $\begin{array}{l}\text { 10. You are one of the most important people to follow all the related } \\
\text { law to prevent disease transmission. }\end{array}$ & 87 (7I.9) & $25(20.7)$ & $9(7.4)$ & $0(0.0)$ & $0(0.0)$ \\
\hline
\end{tabular}


Table 7 Number and percentage of the questions on practice level toward compliance with the abattoir laws $(n=|2|)$

\begin{tabular}{lll}
\hline Questions & Number & Percentage \\
\hline $\begin{array}{l}\text { I. Is your working place registered with } \\
\text { the Ministry of Agriculture and }\end{array}$ & 107 & 88.4 \\
$\begin{array}{l}\text { Agro-based Industry? } \\
\text { 2. Do you only receive animals that } \\
\text { appear healthy from farm or market? }\end{array}$ & 106 & 87.6 \\
$\begin{array}{l}\text { 3. Does the veterinarian or a meat } \\
\text { inspector perform their duties regularly? }\end{array}$ & 104 & 86.0 \\
$\begin{array}{l}\text { 4. Do you use protective clothing on a } \\
\text { daily basis before starting operation } \\
\text { in an abattoir? }\end{array}$ & 108 & 89.3 \\
$\begin{array}{l}\text { 5. Is antemortem examination carried } \\
\text { out before slaughter of each animal? }\end{array}$ & 106 & 87.6 \\
6. Are carcasses condemned either \\
$\begin{array}{l}\text { totally or partially if found unfit for } \\
\text { human consumption? }\end{array}$ & 106 & 87.6 \\
$\begin{array}{l}\text { 7. Is clean water used for washing carcasses } \\
\text { after processing? }\end{array}$ & 110 & 90.9 \\
8. Are carcasses weighed and graded & 94 & 77.7 \\
$\begin{array}{l}\text { before being sold? } \\
\text { 9. Are all solid, blood, and any form of } \\
\text { effluent from the abattoir properly } \\
\text { disposed as required by the regulation/law? }\end{array}$ & 103 & 85.1 \\
$\begin{array}{l}\text { I0. Is the abattoir environment clean and } \\
\text { hygienically maintained regularly? }\end{array}$ & 104 & 86.0 \\
\hline
\end{tabular}

Note: Only questions with high numbers and percentages were recorded.

pest control. Additionally, $60.0 \%$ of the abattoirs visited had good personal hygiene. Moreover, the general condition of more than half $(63.0 \%)$ of the abattoirs was good. However, in the entire abattoirs visited, no records of their activities were presented during the data collection. Based on the personal observation made between the abattoirs, some differences were seen. Some of the abattoirs were cleaner and environmentally friendly than others regarding personal hygiene, environmental sanitation, and use of water guards at their entrances that could prevent transmission of pathogens from the visitors and the workers themselves to the abattoir premises. However, in one of the abattoirs surveyed, the operational activities were poor in such a way that most of

Table 8 Association between sex and knowledge $(n=|2|)$

\begin{tabular}{lllllll}
\hline $\begin{array}{l}\text { Knowledge } \\
\text { level }\end{array}$ & Sex & & & & \\
\cline { 2 - 6 } & Male, & Female, & Total, & $\chi^{2}$ & df & P-value \\
& $\mathbf{n}(\%)$ & $\mathbf{n}(\%)$ & $\mathbf{n}(\%)$ & & & \\
\hline Low & $38(80.9)$ & $9(19.1)$ & $47(100.0)$ & & & \\
Medium & $33(80.5)$ & $8(19.5)$ & $4 I(100.0)$ & $40.515^{\mathrm{a}}$ & $\mathrm{I}$ & $<0.00 I^{\text {a }}$ \\
High & $6(18.2)$ & $27(81.8)$ & $33(100.0)$ & & & \\
Total & $77(63.6)$ & $44(36.4)$ & $121(100.0)$ & & \\
\hline
\end{tabular}

Note: 'Pearson's $\chi^{2}$ test.

Abbreviation: $d f$, degrees of freedom.
Table 9 Association between sex and practice $(n=121)$

\begin{tabular}{lllllll}
\hline $\begin{array}{l}\text { Practice } \\
\text { level }\end{array}$ & Sex & & & & & \\
\cline { 2 - 6 } & Male, & Female, & Total, & $\chi^{2}$ & df & P-value \\
& $\mathbf{n}(\%)$ & $\mathbf{n}(\%)$ & & & \\
\hline Poor & $4(80.0)$ & $\mathrm{I}(20.0)$ & $5(100.0)$ & & & \\
Fair & $18(81.8)$ & $4(18.2)$ & $22(100.0)$ & $4.060^{\mathrm{a}}$ & $\mathrm{I}$ & $0.044^{\mathrm{a}}$ \\
Good & $55(58.5)$ & $39(41.5)$ & $94(100.0)$ & & & \\
Total & $77(63.6)$ & $44(36.4)$ & I2I (100.0) & & \\
\hline
\end{tabular}

Note: aLinear-by-linear test.

Abbreviation: $d f$, degrees of freedom.

their equipments were left unwashed with some blood clot on them in an open space after meat processing and the premises was not comfortable for both the workers and visitors. The variations in hygiene practice and compliance with the abattoir laws could be associated with lack of motivation from some of the management.

\section{Discussion}

Determination of KAP toward compliance with the abattoir laws among the abattoir workers is an issue of great concern in Malaysia. This could be due to the rapid increase in the number of unlicensed meat processing industries, especially in Terengganu. The KAP results of this study showed that the demographic data were not correlated with the level of practice scores except for sex. This study revealed that only sex had a significant association with the level of practice behavior regarding compliance with abattoir laws among the workers. The males had the better practice behavior of compliance with abattoir laws than the females. However, statistically, the females $(81.8 \%)$ had a higher level of knowledge than the males $(18.2 \%)$ even though, based on our personal interview and observation made among the workers, the males seemed to be more knowledgeable with regard to the abattoir laws compared to the females. The good practice displayed among the male workers could be attributed to the higher proportion of the males as well as their boldness and confidence than the females. Even though the previous

Table 10 Association between knowledge and practice $(n=|2|)$

\begin{tabular}{lllll}
\hline $\begin{array}{l}\text { Knowledge } \\
\text { level }\end{array}$ & \multicolumn{4}{l}{ Practice category } \\
\cline { 2 - 5 } & $\begin{array}{llll}\text { Poor, } \\
\mathbf{n}(\%)\end{array}$ & $\begin{array}{l}\text { Fair, } \\
\mathbf{n}(\%)\end{array}$ & $\begin{array}{l}\text { Good, } \\
\mathbf{n}(\%)\end{array}$ & $\begin{array}{l}\text { Total, } \\
\mathbf{n}(\%)\end{array}$ \\
\hline Low & $3(60.0)$ & $12(54.5)$ & $32(34.0)$ & $47(38.8)$ \\
Medium & $2(40.0)$ & $8(36.4)$ & $31(33.0)$ & $4 I(33.9)$ \\
High & $0(0.0)$ & $2(9.1)$ & $31(33.0)$ & $33(27.3)$ \\
Total & $5(100.0)$ & $22(100.0)$ & $94(100.0)$ & $121(100.0)$ \\
$\chi^{2}=6.904^{\mathrm{a}}$ & $d f=I$ & & $P=0.09^{\mathrm{a}}$ & \\
\hline
\end{tabular}

Note: aLinear-by-linear test.

Abbreviation: df, degrees of freedom. 
KAP study was not carried out among abattoir workers, the findings of this study were not consistent with those of the previous KAP study conducted on dengue fever prevention (the females had better practice behavior than the males). ${ }^{14}$

The level of education had no association with the level of practice of compliance with the abattoir laws. The absence of association does not mean that education was not an important factor, but there could be other reasons that made the workers fail to apply their education in practice. Workers have been usually well equipped with the technical knowhow regarding their work, but due to the high demand for the top management in achieving the daily target, sometimes they are careless to put them into practice. However, a study conducted on the typology of the Cameroon traditional slaughterhouses based on hygiene practices found that the level of noncompliance was higher among illiterate workers or workers with a low level of education. ${ }^{15}$ There was also no statistically significant association between marital status and the level practice toward compliance with abattoir laws among the workers. The result of this study indicated that marital status had no negative effect with regard to the practice of compliance with abattoir laws.

The mean score of knowledge was found to be 6.02 from a possible 10 points with an SD of 1.954. The low mean score was clearly an indication that the majority of the workers who participated in this study had a low level of knowledge (38.8\%). Based on the findings of this study, $27.3 \%$ of the workers had higher knowledge and 33.9\% had moderate knowledge. The low educational level was evident from their demographic characteristics that only $2.5 \%$ of the workers had attended tertiary institutions. The highest average percentage scored by the workers was on the questions on the importance of compliance with abattoir laws in minimizing the spread of diseases to the general public. The responses indicated that $92.6 \%$ were aware that compliance with abattoir laws helps in reducing the spread of diseases to the public. Similarly, the workers had good knowledge on the question regarding complying with meat processing hygiene could prevent the spread of pathogens to the general public. A higher percentage (87.6\%) of the workers answered the question correctly. Another area where the workers $(83.5 \%)$ answered correctly was the question of noncompliance, meaning failure to act according to the rules and regulations set up by the government. The result of this study was not consistent with the study conducted by previous researchers, ${ }^{16,17}$ who found that the level of knowledge of hygiene and safety standards among the workers was low. The majority of the workers $(66.1 \%)$ had wrongly answered the question of noncompliance does not result in transmission of disease from animal to human beings. Only 33.9\% of the workers had good knowledge that noncompliance could result in the transmission of diseases from animal to human beings. Therefore, this indicated that most of the workers were not aware of zoonotic diseases that could be detrimental to their health. Moreover, another important area where the workers had a knowledge deficit was on the question regarding postmortem inspection could be done by any person working at the abattoir. More than half of the workers (51.2\%) incorrectly answered the question regarding the personnel responsible for postmortem inspection at abattoirs. Postmortem inspection is one of the critical points in meat processing plants; failure to comply with the abattoir laws in this regard might result in transmission of pathogens to the general public. This study was in agreement with the study conducted previously that states that poor awareness and knowledge of zoonosis combined with food consumption habits and poor animal husbandry were likely to expose respondents to an increased risk of contracting zoonosis. ${ }^{18}$ It is also consistent with the past KAP survey among the abattoir workers in Adamawa, Nigeria, that states that the majority of the workers had low knowledge regarding zoonotic infection. ${ }^{19}$

The mean survey score for the attitude toward compliance with abattoir laws was 45.16 from a possible 50 points with an SD of 4.50. It was evidently seen that the workers had a positive attitude $(91.7 \%)$. Interestingly, their positive attitude might be the reason behind their good practice $(77.7 \%)$ toward compliance with abattoir laws. The findings of this study showed no significant association between attitude and practice of compliance with abattoir laws among the workers. The results of this study were in agreement with the KAP study conducted among the rural communities and family health leaders on dengue prevention. ${ }^{14,20,21}$ The study also found that there was no association between knowledge and attitude among the workers. This study found few areas of negative attitude toward compliance with the abattoir laws among the abattoir workers. Only $36.4 \%$ of the workers strongly agree that the government should compensate owners whose animals were found not fit for human consumption. The lack of compensation contributed to the noncompliance by some workers since they could not force animal owners to slaughter their animal in registered abattoirs. It was also revealed in our study that animals found with zoonotic diseases at the antemortem inspection should not be condemned completely as reported by $51.2 \%$ of the abattoir workers. Therefore, this could be of public health importance due to failure to partially or completely condemn diseased animals, which could pose a danger of transmitting deadly pathogens to the public. 
The mean survey score for the practice toward compliance with abattoir laws was 18.03 from a possible 20 points with an $\mathrm{SD}$ of 3.82. The highest mean score showed that the workers had a good practice $(77.7 \%)$ toward compliance with abattoir laws. There was a significant association between knowledge and the level of practice toward compliance with abattoir laws among the abattoir workers. Additionally, the result of correlation analysis also indicated a significant correlation between knowledge and practice level among the workers. The association indicated that those workers who had a low level of knowledge tend to have high percentage (32 [34.0\%]) of good practice than those with high level of knowledge (31 [33.0\%]) toward compliance with abattoir laws. The findings of this study were also in line with the KAP study conducted regarding the prevention of occupational hazards and attitude toward utilization of safety measures among meat workers in the North Indian settings, which reported a significant relationship between knowledge and practice score. ${ }^{22}$ They also added that meat workers had a better score for practice about occupational hazards before starting the work than during work and after the work. The inconsistent practice could be associated with the workload performed during the operation or lack of motivation by the top management.

The main limitation of this study was the exclusion of the abattoir workers from the unlicensed slaughterhouses, who constitute the majority of the abattoirs in Terengganu. The reason was due to the limited time frame and insufficient resources while conducting the research. Based on the outcome of this study, it was assumed that the KAP score of the unlicensed abattoirs was lower than that of the licensed abattoirs in the state. A recent study conducted in Cameroon among the slaughterhouse workers indicated that the bad practices of hygiene were linked to illiteracy and traditional slaughterhouses. ${ }^{15}$ The bad practices could be because the majority of these traditional slaughterhouses were not licensed. During the data collection process in this study, it was observed that some of the unlicensed slaughtering premises along the roadside were busy butchering animals on tables and unhygienic floors very early in the morning. In most of the developing countries, meat processing is unhygienic from slaughtering, dressing, and evisceration done on the floor in slaughter halls and slabs. ${ }^{23}$ Moreover, illegally slaughtered carcasses pose a danger to human health as no inspection is carried out by a qualified veterinarian, to ensure that quality meat is supplied to the general public that is free from diseases and parasites that could transmit zoonosis. ${ }^{24}$ Since most of these illegal premises were own by private organizations and the government does not have control over them, standard hygiene control and monitoring becomes an issue of concern for the government.

\section{Conclusion and recommendations}

The was no correlation with the level of knowledge between the demographic variables (education, marital status, employment status, etc) except for sex. The females had a higher level of knowledge than the males, while the males had the better practice behavior of compliance than the females. Similarly, the level of education had no association with the level of practice of compliance with abattoir laws. The findings also indicated that the majority of the workers had a low level of knowledge but had a positive attitude and good practice toward compliance with abattoir laws. Furthermore, there was a significant association between the level of knowledge and practice. However, workers who had a low level of knowledge regarding abattoir laws were found to be of good practice toward compliance with rules and regulations governing the abattoir operation. Therefore, the abattoir workers had a positive attitude and good practice but a low level of knowledge toward compliance with abattoir laws.

Based on the outcome of this study, public education and enlightenment regarding the risk associated with noncompliance with abattoir laws, particularly to the abattoir workers, should be routinely practiced through mass media. Similarly, future educational programs in the mode of the spread of pathogens, zoonotic diseases, and personnel to carry out meat inspection should be properly taken into account for an effective compliance with abattoir laws. However, a proper motivation of the workers toward maintaining a positive attitude and good practice regarding compliance with abattoir laws as well as enforcing all the existing laws governing the abattoir operation in the country should be encouraged. It is also recommended that future research should focus on the determination of KAP and the level of compliance with abattoir laws in both licensed and unlicensed slaughterhouses across the State.

\section{Acknowledgment}

The authors would like to acknowledge the support and their sincere appreciation to all the abattoir workers in Terengganu who had actively participated in this research work.

\section{Disclosure}

The authors report no conflicts of interest in this work.

\section{References}

1. Bangkok, Thailand: Regional Office for Africa. Developing and maintaining food safety control systems for Africa Current Status and prospects for change, Second FAO/WHO Global Forum of Food Safety Regulators, Bangkok, Thailand: Regional Office for Africa; 2004:12-14. 
2. Subratty AH, Gurib FBH. Consumers' concern about the meat product quality offered for sale in Mauritius. Nutrit Food Sci. 2003;33(2):80-83.

3. Centre for Disease Control. Surveillance for foodborne disease outbreaks, United States, 1988-1992. Morb Mortal Wkly Rep. 1996;4(5):1-73.

4. Holt G, Henson SJ. Quality assurance management in small food manufacturers. Food Control. 2000;11(4):319-326.

5. Aluko OO, Ojeremi TT, Olaleke DA, Ajidagba EB. Evaluation of food safety and sanitary practices among food vendors at car parks in Ile-Ife, southwestern Nigeria. Food Control. 2014;40:165-171.

6. Otsuki T, Wilson JS, Sewadeh M. Saving two in a billion: quantifying the trade effect of European food safety standards on African exports. Food Policy. 2001;26(5):495-514.

7. Jacob C, Mathiasen L, Powell D. Designing effective messages for microbial food safety hazards. J Food Contr. 2010;21:1-6.

8. Griffith CJ. Food safety: where from and where to? $\mathrm{Br}$ Food J. 2006;108(1):6-15

9. Redmond EC, Griffith CJ. Consumer food handling in the home A review of food safety studies. J Food Prot. 2003;66:130-161.

10. World Health Organization. Foodborne Disease: A Focus for Health Education. Geneva: World Health Organization; 2001:198. Can Vet J. 2002;43(9):717. [cited Oct 3, 2015]. Available from: http://www.ncbi nlm.nih.gov/pmc/articles/PMC339561/. Accessed October 01, 2015.

11. Kuala Terengganu Annual Conference. KT2014 Annual Conference about Terengganu; 2014. [The webLog post]. Available from: Kt2014 blogspot.com/p/about-terengganu-darul iman.html/2014/07/10 Accessed September 09, 2015.

12. Barman A. Applied Statistics in Research. Malaysia: UniSZA; 2015.

13. Wesson DW. Biostatistics: A Foundation for Analysis in the Health Sciences. 8th ed. Lexington, SC: John Wiley and Sons Inc; 2006.

14. Nahida A. Knowledge, attitude and practice of dengue fever prevention among the people in male, Maldives, Published Master's Dissertation, Chulalongkorn, University, Thailand, 2007.
15. Raoul BA, Rodrigue PN, Sylvain SK, Victor NN, Jean JEN. Typology of the Cameroon traditional slaughterhouses based on hygiene practices. Adv Animal Vet Sci. 2014;2(8):487.

16. Peter MK. Food safety knowledge and practices among actors in a beef chain with reference to Rift Valley fever outbreak in Maragua District, Kenya, Published Master's Dissertation, 2012.

17. Mekonnen H, Habtamu T, Kelali A, Shewit K. Food safety knowledge and practices of abattoir and butchery shops and the microbial profile of meat in Mekelle City, Ethiopia. Asian Pac J Trop Biomed. 2013;3(5):407-412.

18. Emanuel S, Swai LS, Chris JD. Knowledge and attitude towards zoonosis among animal health workers and livestock keepers in Arusha and Tanga, Tanzania. Tanzan J Health Res. 2010;12(4):1-8.

19. Bakari NA, Umoh JU, Kabir J, et al. A case study of Yola Modern Abattoir, Adamawa State, Nigeria. J Vet Adv. 2015;19(2):995-1003.

20. Hairi F, Ong CH, Suhaimi A, et al. A knowledge, attitude and practices (KAP) study on dengue among selected rural communities in the Kuala Kangsar district. Asia Pac J Public Health. 2003;15(1):37-43.

21. Limros T. Preventive behaviors against dengue infection among family health leaders in Kongkrailat District, Sukhothai Province, Published Masters Dissertation, Chulalongkorn, University, Thailand, 2006.

22. Anish K. To Evaluate the knowledge and practice regarding prevention of occupational hazards and attitude towards utilization of safety measures among meat workers in north Indian setting: a cross-sectional study. J Int Acad Res Multidisciplinary. 2013;1(11):1-8.

23. Adeyemo OK. Unhygienic operations of a city abattoir in South Western Nigeria: environmental implication. Ajeam/Rage. 2002;4(1):23-28.

24. Tabitha MS. Bacteriological quality of meat in Lesotho, Published Thesis, Magister Scientiae in the Department of Paraclinical Sciences, Faculty of Veterinary Science, University of Pretoria, South Africa, 2009.
International Journal of General Medicine

\section{Publish your work in this journal}

The International Journal of General Medicine is an international, peer-reviewed open-access journal that focuses on general and internal medicine, pathogenesis, epidemiology, diagnosis, monitoring and treatment protocols. The journal is characterized by the rapid reporting of reviews, original research and clinical studies across all disease areas.

\section{Dovepress}

A key focus is the elucidation of disease processes and management protocols resulting in improved outcomes for the patient. The manuscript management system is completely online and includes a very quick and fair peer-review system. Visit http://www.dovepress.com/ testimonials.php to read real quotes from published authors. 